University of Chicago Law School

Chicago Unbound

Public Law and Legal Theory Working Papers

Working Papers

2013

\title{
Lafler and Frye: Two Small Band-Aids for a Festering Wound
}

Albert W. Alschuler

Follow this and additional works at: https://chicagounbound.uchicago.edu/public_law_and_legal_theory

Part of the Law Commons

Chicago Unbound includes both works in progress and final versions of articles. Please be aware that a more recent version of this article may be available on Chicago Unbound, SSRN or elsewhere.

\section{Recommended Citation}

Albert Alschuler, "Lafler and Frye: Two Small Band-Aids for a Festering Wound" (University of Chicago Public Law \& Legal Theory Working Paper No. 430, 2013).

This Working Paper is brought to you for free and open access by the Working Papers at Chicago Unbound. It has been accepted for inclusion in Public Law and Legal Theory Working Papers by an authorized administrator of Chicago Unbound. For more information, please contact unbound@law.uchicago.edu. 


\title{
CHICAGO
}

PUblic LAW AND LegAL THEORY WORKING PAPER No. 430

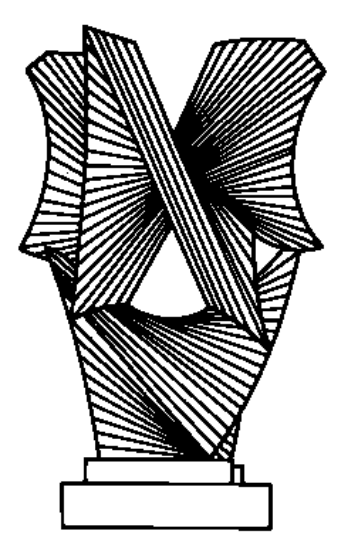

\section{LAFLER AND FRYE: TWO SMALL BAND-AIDS FOR A FESTERING WOUND}

Albert W. Alschuler

\author{
THE LAW SCHOOL \\ THE UNIVERSITY OF CHICAGO
}

June 2013

This paper can be downloaded without charge at the Public Law and Legal Theory Working Paper Series: http://www.law.uchicago.edu/academics/publiclaw/index.html and The Social Science Research Network Electronic Paper Collection. 


\title{
Lafler and Frye: Two Small Band-Aids for a Festering Wound
}

\author{
Albert W. Alschuler*
}

I. Two Astonishing THINGS ABOUT LAFLER

AND FRYE: THE DISSENTING AND

MAJORITY OPINIONS

II. LOOKING FOR LANDMARKS IN ALL THE

WRONG PLACES....

III. Mission IMPOSSIBLE: GUARANTEEING THE

EFFECTIVE ASSISTANCE OF COUNSEL IN THE

Plea Negotiation PROCESS

IV. THE ALCHEMY OF AMERICAN TRIALS:

TURNING GOLD INTO LEAD

A. Finding a Baseline

B. An Unconvincing Study

C. $\quad$ The Expected Difference Between

Sentences Imposed Following Trials and

Those Imposed Following Guilty Pleas.

D. A Hard Look at the Post-Trial Baseline .......... 696

V. CONCLUSION ......................................................... 704

Imagine that you are on death row, and imagine that the incompetence of your lawyer has put you there. A witness at your trial testified that you waited at the wheel of a getaway car while two accomplices robbed a liquor store and one of them shot and killed the clerk. Shortly after your arrest, the prosecutor offered to permit you and your co-defendants to plead guilty to voluntary manslaughter and armed robbery. This offer would have limited your sentence to 25 years. ${ }^{1}$ Your co-defendants, including the alleged triggerman, accepted the offer. You would have accepted the offer too if your lawyer had told you about it, but he never did.

* Julius Kreeger Professor of Criminal Law and Criminology, Emeritus, the University of Chicago.

1. Sandra Lockett turned down an offer like this one before being convicted and sentenced to death. See Lockett v. Ohio, 438 U.S. 586, 591 (1978). 


\section{Two Astonishing Things ABout LAFLER AND FRYE: THE DISSENTING AND MAJORITY OPINIONS}

Two things astonish me about the decisions in Lafler $v$. Cooper ${ }^{2}$ and Missouri $v$. Frye. ${ }^{3}$ The first is that four justices of the United States Supreme Court would allow your lawyer's incompetence to kill you. These justices appear incredulous that anyone might think you were treated unfairly.

One of these dissenting justices, Justice Scalia, proclaims that you "received the exorbitant gold standard of American justice-a full-dress criminal trial." ${ }^{4}$ He argues that the people who object to your execution "embrace[] the sporting-chance theory of criminal law, in which the State functions as a conscientious casinooperator, giving each player a fair chance to beat the house, that is, to serve less time than the law says he deserves."

In Justice Scalia's view, you'll get what you deserve while your co-defendants just got lucky. Never mind that the prosecutor initially acknowledged that public justice did not require your execution; never mind that, through no fault of your own, you did not get the sentence the American legal system considers normal for offenders like you; and never mind that, despite the Constitution's promise of the assistance of counsel, it was your lawyer who did you in. In the American legal system, you got the gold.

When defense lawyers have slept through their trials, courts have noted that a sleeping lawyer is the equivalent of no lawyer at all. $^{6}$ Your lawyer, however, was worse than no lawyer at all. Without him, the prosecutor would have made his offer directly to you, and you would not be on death row. The state licenses lawyers so that people like you can rely on them, but if Justice Kennedy, the second most powerful man in America, had voted the other way, the Court would allow your execution.

\footnotetext{
2. 132 S. Ct. $1376(2012)$

3. 132 S. Ct. 1399 (2012).

4. Lafler, 132 S. Ct. at 1398 (Scalia, J., dissenting).

5. Id. Justice Thomas joined the portion of Justice Scalia's dissenting opinion that includes this rhetoric. Chief Justice Roberts joined an earlier portion that made the same point less flamboyantly: "The defendant has been fairly tried, lawfully convicted, and properly sentenced, and any 'remedy' provided for this will do nothing but undo the just results of a fair adversarial process." Id. at 1397. In a separate dissenting opinion, Justice Alito declared, "Respondent received a trial that was free of any identified constitutional error, and, as a result, there is no basis for concluding that respondent suffered prejudice ...." Id. at 1398 (Alito, J., dissenting).

6. See Burdine v. Johnson, 262 F.3d 336, 349 (5th Cir. 2001) (en banc); Javor v. United States, 724 F.2d 831, 834 (9th Cir. 1984).
} 
Stephanos Bibas describes the division between the majority and dissenting opinions as "a jurisprudential one rooted in biography and outlook."7 Justice Scalia, he says, "approaches matters as an originalist ...., regulating the eighteenth-century world of the Framers."

In fact, nothing at all seems "originalist" about Justice Scalia's position. Substituting a regime of plea bargaining for the regime of jury trials ostensibly safeguarded by the Constitution would have appalled the authors of that document. ${ }^{9}$ The courts of their era strongly discouraged guilty pleas and held confessions induced by promises of leniency involuntary. ${ }^{10}$

Even if one can imagine that the Framers would have countenanced a regime of plea bargaining, it is difficult to believe they would have withheld a right to the assistance of counsel in the process that superseded the one they knew. ${ }^{11}$ Like all the other justices of the Supreme Court, Justice Scalia genuflects before the perceived necessity of plea bargaining. ${ }^{12}$ There are no originalists there. ${ }^{13}$

The second thing that astonishes me about Lafler and Frye is that the remaining five justices of the Supreme Court might also leave you on death row. While acknowledging that your constitutional rights were violated, they would allow the judge who tried and sentenced you to do nothing about it. The majority declares that the "correct" remedy in cases like yours

7. Stephanos Bibas, Taming Negotiated Justice, 122 YALE L.J. ONLINE 35, 38 (2012)

8. Id.

9. The Constitution declares that "[t]he Trial of all Crimes . . shall be by Jury . . ," U.S. CONST. art. III, $\S 2$, and that "[i]n all criminal prosecutions, the accused shall enjoy the right to a speedy and public trial, by an impartial jury." U.S. CONST. amend. VI. As John Langbein notes, Americans now can replace the word "all" in these provisions with the words "virtually none." See John H. Langbein, On the Myth of Written Constitutions: The Disappearance of Criminal Jury Trial, 15 HARV. J.L. \& PUB. POL. 119, 119-20 (1992).

10. See Albert W. Alschuler, Plea Bargaining and Its History, 79 CoLUM. L. REv. 1, 7 13 (1979).

11. The defendants in Lafler and Frye had the assistance of counsel at trial, but the lack of effective legal assistance kept them from obtaining the benefits of America's "real" legal system. I doubt that the Framers would have cheered.

12. See Lafler v. Cooper, 132 S. Ct. 1376, 1397 (Scalia, J., dissenting) ("In the United States, we have plea bargaining a-plenty, but until today it has been regarded as a necessary evil.").

13. Cf. Albert W. Alschuler, Herring v. United States: A Minnow or a Shark?, 7 OHIO ST. J. CRIM. L. 463, 501-11 (2009) (noting that justices who criticize the Fourth Amendment exclusionary rule because it was unknown to the Framers have restricted the remedies that were known to the Framers in ways they never would have approved). 
is to order the State to reoffer the plea agreement. Presuming the respondent accepts the offer, the state trial court can then exercise its discretion in determining whether to vacate the conviction[] and resentence respondent pursuant to the plea agreement ... or to leave the conviction[] and sentence from trial undisturbed. ${ }^{14}$

Notice that the issue is not whether the court would have accepted your guilty plea and sentenced you in accordance with the agreement if your lawyer had been competent. It is whether sentencing you in accordance with the agreement feels like a good idea today.

The usual goal of legal remedies is to place the victim of a wrong in the position he would have occupied had the wrong not occurred, and doubts about what position he would have occupied usually are resolved against the wrongdoer. For example, before a constitutional trial error can be treated as harmless, the state usually must demonstrate "beyond a reasonable doubt that the error complained of did not contribute to the verdict obtained."15

When the Supreme Court wishes to disregard this principle, however, it reshapes the constitutional right. You may believe, for example, that you have a right to the effective assistance of counsel, but the Supreme Court says you don't. You have only a right to counsel whose ineffectiveness does not undermine confidence in the outcome of your trial. To establish a violation of this right, you must show not only that your "counsel made errors so serious that counsel was not functioning as the 'counsel' guaranteed by the Sixth Amendment" but also that your counsel's "deficient performance prejudiced the defense" by depriving you of "a fair trial, a trial whose result is reliable." ${ }^{\text {"16 }}$ With the Sixth Amendment right reconfigured in this way, the state need not show that your lawyer's inadequate performance was harmless. You must show that it wasn't.

This standard has been in place for nearly thirty years. Frye says that it requires you to demonstrate not only your lawyer's defective performance but also a "reasonable probability" of two additional things-first, that you would have accepted the prosecutor's offer if your lawyer had told you about it and, second, that

14. Lafler, 132 S. Ct. at 1391.

15. Chapman v. California, 386 U.S. 18, 24 (1967).

16. Strickland v. Washington, 466 U.S. 668,686 (1984). 
the court would have approved the deal. ${ }^{17}$ Those requirements come as no surprise, but satisfying them may not get you off death row. Satisfying these requirements will merely establish a violation of your right to counsel. Lafler then leaves the question of remedy to the trial judge's discretion. He may restore you to the position you would have occupied if your lawyer had been competent, or he may not. ${ }^{18}$

17. 132 S. Ct. at 1409

18. The Supreme Court apparently declined to order implementation of the sentence a capable lawyer would have obtained for you because the evidence presented at your trial might have shown that this sentence was too lenient. For example, an accomplice might have testified that you proposed robbing the liquor store, supplied the firearms, and instructed your confederates to leave no witness alive. The prosecutor might have been unaware of your accomplice's allegations when he made his offer, and the judge might have been convinced by the accomplice's testimony.

When a legal system is so indifferent to the truth that it bribes defendants not to contest the prosecutor's evidence or present any evidence of their own, it seems odd to insist that sentencing judges must be able to consider every circumstance that has emerged as a result of violating a defendant's rights. In many cases each day, courts impose sentences pursuant to plea agreements that they might have considered too lenient had they examined the evidence, and if the truth later emerges, the defendants' sentences remain final. Should your case be different simply because you had an inadequate lawyer?

The Supreme Court majority apparently answers this question yes, and perhaps you would have received a clearly undeserved break had your lawyer done his job. Even so, the Court might have hesitated before substituting a regime of judicial discretion for the customary (if sometimes too generous) remedial principle.

When the sentence a judge has imposed after a trial differs from the sentence the prosecutor offered before trial, the judge is likely to consider the sentence he imposed more appropriate. Is the judge's conclusion that the pretrial offer would constitute inadequate punishment a sufficient reason for him to deny a remedy? Could he deny a remedy for this reason in every case, thereby nullifying the rulings in Lafler and Frye? Or must the judge conclude that the sentence offered by the prosecutor was grossly inappropriate or flagrantly unjust? Must the judge find that the prosecutor was unaware of a relevant circumstance at the time he made his offer? (It probably would not be difficult for a judge who has conducted a trial and examined a presentence investigation report to make such a finding.) What if the judge exercised his discretion on a different basis-concluding, for example, that he should give the defendant only the benefit of whatever portion of the prosecutor's offer was "driven by fairness concerns"? See Wesley M. Oliver, The Indirect Potential of Lafler and Frye, 51 DUQ. L. REV. 640-41, 645 (2013).

A defendant denied a remedy would be likely to allege an abuse of the judge's discretion on appeal. In a legal system too miserly to implement the defendant's right to trial, does devoting significant resources to delineating the boundaries of a judge's discretion not to remedy a constitutional violation make sense? Are the many issues posed by the LaflerFrye ruling on remedies worth resolving? Recall that a court will consider these issues only after a defendant has shown that his lawyer was inadequate, that he would have accepted the prosecutor's offer, and that a court would have approved the agreement. See generally Jenia Iontcheva Turner, Effective Remedies for Ineffective Assistance, 48 WAKE FOREST L. REV. (forthcoming 2013) (manuscript on file with author).

In Burt v. Titlow, 2013 WL 656043 (Feb. 25, 2013) (order granting certiorari), the Supreme Court will consider what remedy, if any, to provide when a lawyer's ineffective assistance led a defendant to withdraw from an agreement that would have required her to testify against an alleged accomplice. Following the lawyer's ineffective assistance, the purported accomplice was tried and acquitted without the defendant's testimony, and the 


\section{LOOKING FOR LANDMARKS IN ALL THE WRONG PlACES}

Those are the things I find remarkable about Lafler and Frye, but I am a pessimist who sees the glass as nine-tenths empty. More cheery people observe that the glass is one-tenth full. Indeed, in a heartwarming demonstration of the will to believe, some claim that Lafler and Frye will be remembered as landmarks.

Wesley Oliver, for example, told the New York Times, "The Supreme Court's decisions in these two cases constitute the single greatest revolution in the criminal justice process since Gideon $v$. Wainwright provided indigents the right to counsel."19 Stephanos Bibas wrote, "After four decades of neglecting laissez-faire plea bargaining, the Supreme Court got it right . . . . Finally, the Court has brought law to the shadowy plea-bargaining bazaar." 20 Ronald Wright told the Times, "I can't think of another decision that's had any bigger impact than these two are going to have over the next three years." Wright observed that, although plea bargaining has been the rule rather than the exception for generations, "the Supreme Court has, until the last two or three years, found a way to ignore that." The Court is like "Rip Van Winkle waking up. He looks around and says, "Wow, when I went to sleep the world was full of trials." 21 Others have used words like "bold," "huge," 22 and "game-changing."

defendant herself was tried, convicted, and sentenced to a term of twenty-to-forty years (rather than the seven-to-fifteen years she would have received under the abandoned agreement). The government argues that, because it cannot be restored to the position it would have occupied had the agreement been fulfilled, the defendant should not be restored to the position she would have occupied either. See Titlow v. Burt, 680 F.3d 577 (6th Cir. 2012).

Whenever ineffective legal assistance leads to an unnecessary post-trial penalty (as in Lafler and Frye themselves), the defendant cannot give the government what it bargained for. He can no longer save the government the cost of a trial. The fact that the defendant, through no fault of his own, cannot fulfill his part of the bargain provides no reason to deny him a remedy. The Constitution promised him effective legal assistance, and when his attorney failed to provide it, it was the government that defaulted on a core promise. Like the defendant, the prosecutor's office might have been blameless. It is nevertheless appropriate for the government rather than the defendant to bear the consequences of a governmental default by restoring the defendant to the position he would have occupied had the constitutional promise been fulfilled.

19. Adam Liptak, Justices Expand Rights of Accused in Plea Bargains, N.Y. TIMES, Mar. 22, 2012, at A1; see Gideon v. Wainwright, 372 U.S. 335 (1963).

20. Bibas, supra note 7, at 35 .

21. Erika Goode, Stronger Hand for Judges in the "Bazaar" of Plea Deals, N.Y. TIMES, Mar. 23, 2012, at A12.

22. Id. 
... decisions in Missouri v. Frye and Lafler v. Cooper, a new era in the jurisprudence of the Sixth Amendment has begun." ${ }^{24}$

These remarks bring to mind some notable words of Justice Holmes: "Oh bring in a basin." 25 One reason the gush is unwarranted is that Lafler and Frye did not change the law. For more than forty years, the Supreme Court has called plea bargaining an "essential part of the [criminal] process" ${ }^{26}$ and has recognized that defendants have a right to the assistance of counsel in evaluating offers and deciding whether to plead guilty. ${ }^{27}$ Indeed, this right is just about the only right defendants who plead guilty still have.

The Court wrote in McMann v. Richardson in 1970, "In our view a defendant's plea of guilty based on reasonably competent advice is an intelligent plea ...." ${ }^{28}$ It declared in Tollett $v$. Henderson in 1973 that a defendant who pleads guilty "may only attack the voluntary and intelligent character of the guilty plea by showing that the advice he received from counsel was not within the standard set forth in McMann.."29 In 1985, the Court indicated that an attorney's mistaken advice concerning a defendant's eligibility for parole could invalidate a guilty plea, but only if the defendant could show that suitable advice would have led him to stand trial. $^{30}$ In 2010, the Court held an attorney's performance deficient because he failed to advise a client that a guilty plea could lead to his deportation, but the Court did not consider whether the client had shown prejudice. ${ }^{31}$

To be sure, until Lafler and Frye, the Court had not considered a claim that a lawyer's deficient performance had produced, not an ill-advised guilty plea, but an avoidable post-trial penalty. Eleven of the twelve federal courts of appeals, however, had considered

23. Cynthia Alkon, Plea Bargaining, Just as it Ever Was?, ThE MAYHEW-Hite REPORT ON DisPute RESOlution AND THE COURTS, (May 2012), http://moritzlaw.osu.edu/epub/mayhew-hite/2012/05/plea-bargaining-just-as-it-ever-was/.

24. Justin F. Marceau, Embracing a New Era of Ineffective Assistance of Counsel, $14 \mathrm{U}$. PA. J. CONST. L. 1161, 1161 (2012).

25. Sheldon M. Novick, Honorable Justice: The Life of Oliver Wendell Holmes 469 n.11 (1989) (quoting a letter from Holmes to J. H. Wigmore, Nov. 1915).

26. Santobello v. New York, 404 U.S. 257, 261 (1971). The observation that, although television dramas portray trials, the real world is dominated by plea bargains was commonplace forty years ago. Neither the Supreme Court nor any other observer of the American criminal justice system awoke to this truth only yesterday.

27. See the rulings described in the following paragraph.

28. 397 U.S. 759,770 (1970).

29. 411 U.S. 258, 267 (1973). I discuss McMann and Tollett in Albert W. Alschuler, The Supreme Court, the Defense Attorney, and the Guilty Plea, 47 U. CoLO. L. REV. 1 (1975).

30. Hill v. Lockhart, 474 U.S. 52, 58-59 (1985).

31. Padilla v. Kentucky, 130 S. Ct. 1473, 1481 (2010). 
claims of this sort, and all of them had recognized that a defendant was entitled to relief when his lawyer's defective representation caused him to lose a beneficial plea agreement. ${ }^{32}$ Most state courts had agreed, ${ }^{33}$ although a very few had held that a diamondstudded, gold-plated trial could make it immaterial whether a lawyer's faulty performance during plea negotiation produced extra years of imprisonment for his client. ${ }^{34}$

32. See, e.g., United States v. Rodriguez, 929 F.2d 747, 752 (1st Cir. 1991) ("A defendant has a right to be informed of a plea offer. Ordinarily, counsel's failure to do so constitutes ineffective assistance of counsel."); Boria v. Keene, 99 F.3d 492, 496-99 (2d Cir. 1996) (reducing a prisoner's sentence to time served because a lawyer who had advised him of a prosecutor's offer failed to offer his personal assessment of the wisdom of accepting it); United States v. Day, 969 F.2d 39, 44 (3d Cir. 1992) ("Failure by defense counsel to communicate a plea offer to defendant deprives defendant of the opportunity to present a plea bargain for the consideration of the state judge . . . A subsequent fair trial does not remedy this deprivation.”); United States v. Brannon, 48 Fed. Appx. 51, 53, 2002 U.S. App. LEXIS 20969 (4th Cir. 2002) ("Erroneous advice during the plea negotiation process or the failure of a defense attorney to timely inform his client of a plea offer constitutes unreasonable professional assistance."); United States v. Herrera, 412 F.3d 577, 581 (5th Cir. 2005) ("a 27-month increase in a sentence constitutes prejudice"); Cooper v. Lafler, 376 Fed. App'x 563, 573, 2010 U.S. App. LEXIS 95899 (6th Cir. 2010) ("Petitioner lost out on an opportunity to plead guilty and receive the lower sentence that was offered to him because he was deprived of his constitutional right to effective assistance of counsel. Thus, he has established prejudice."), vacated and remanded, 132 S. Ct. 1376 (2012); Julian v. Bartley, 495 F.3d 487, 499 (7th Cir. 2007) ("but for the ill-advice, Julian would have taken the plea"); Nunes v. Mueller, 350 F.3d 1045, 1054 (9th Cir. 2003) (defendant made out a prima facie case of ineffective assistance by alleging that if he had "been informed accurately, he would expressly have taken the bargain"); Williams v. Jones, 571 F.3d 1086, 1091 (10th Cir. 2009) ("the prejudice Mr. Williams identified was that, had he been adequately counseled, there is a reasonable probability that he would have accepted the plea offer"); Oliver v. United States, 292 Fed. App'x 886, 887, 2008 U.S. App. LEXIS 19743 (11th Cir. 2008) (holding that failing to inform the defendant of the government's "eve-of-trial plea offer . . . constitutes deficient performance"); United States v. Mouling, 557 F.3d 658, 669 (D.C. Cir. 2009) (“An evidentiary hearing is necessary to determine whether Mouling knew the details of the plea offer and whether there was a reasonable probability he would have accepted the offer had counsel properly informed him of it.").

33. See e.g., Davie v. State, 675 S.E.2d 416 (S. Car. 2009); Charmichael v. People, 206 P.3d 800 (Colo. 2009); Leake v. State, 737 N.W.2d 531 (Minn. 2007); Dew v. State, 843 N.E.2d 556 (Ind. App. 2006); Jiminez v. State, 144 P.3d 903, 907 (Okla. Crim. App. 2006); Commonwealth v. Mahar, 809 N.E. 2d 989, 993 (Mass. 2004); People v. Gandiaga, 70 P.3d 523, 527 (Colo. App. 2002); State v. Donald, 10 P.3d 1193 (Ariz. App. 2000); State v. Tacetta, 797 A.2d 884 (N.J. Super 2002): State v. Garrison, 40 S.W.3d 426, 430-31 (Tenn. 2000); Ex parte Lemke, 13 S.W.3d 791 (Tex. Crim. App. 2000); In re McCreedy, 996 P.2d 658 (Wash. App. 2000); Becton v. Hun, 516 S.E.2d 762 (W. Va. 1999); People v. Curry, 687 N.E.2d 877 (Ill. 1997); State v. Lentowski, 569 N.W.2d 758 (Wis. 1997); Williams v. State, 605 A.2d 103 (Md. App. 1992); State v. Kraus, 397 N.W.2d 671 (Iowa 1986).

34. See Bryan v. State, 134 S.W.3d 795, 802-03 (Mo. Ct. App. 2004); State v. Greuber, 165 P.3d 1185, 1189 (Utah 2007). In Winward v. State, 293 P.3d 259 (Utah 2012), the Utah Supreme Court acknowledged that Lafler and Frye had repudiated its decision in Greuber. The court observed, however, "Greuber may remain good law to the extent that it guides lower courts in fashioning a remedy." $I d$. at 269 n.12. 
The consensus of the courts prior to Lafler and Frye may not have rested entirely on their concern for defendants' rights. Ensuring that prosecutors' offers reach defendants is in the interest of plea-hungry prosecutors and courts as well as defendants themselves. Ensuring that lawyers convey accurately the coercive power of these offers helps to keep the river of guilty pleas flowing. Deficient lawyering in Lafler and Frye may not only have cost two defendants years of their lives but also required the state to pay the cost of an unnecessary trial. ${ }^{35}$

If the dissenters' views had prevailed, Lafler and Frye would have been revolutionary, but the majority opinions were not. In fact, both majority opinions concluded that the courts below had been too generous in affording relief to the petitioners. ${ }^{36}$ Because Lafler and Frye gave defendants nothing they did not already have, Justice Scalia protested too much when he became the first to award these decisions landmark status: "[T]he Court today opens a whole new field of constitutionalized criminal procedure: plea-bargaining law." 37 It was the author of those words who must have been dozing like Rip Van Winkle.

\section{Mission IMPossible: GuARANTEEING THE EFFECTIVE Assistance of COUNSEL IN THE Plea Negotiation PROCESS}

Even if Lafler and Frye had not fudged the question of remedy and even if these decisions had burst on the scene bold, new, and shiny, they would not warrant the hype bestowed upon them by professors and the press. Three observations about the American legal system I made twenty-seven years ago seem relevant.

First, our plea-dominated system makes the kind of justice a "defendant receives more dependent on the quality of his counsel

35. Only one unnecessary trial. After the prosecutor's offer lapsed in Frye, the defendant pleaded guilty without a bargain.

Josh Bowers notes, "The government may be the unsung winner of Lafler $v$. Cooper and Missouri v. Frye." Josh Bowers, Lafler, Frye, and the Subtle Art of Winning by Losing, 25 FED. SENT'G. REP. 126, 126 (2012). In his view, these decisions "merely have helped guarantee that a defendant has a lawyer good enough to convince him that the prosecutor holds the cards and that he is sunk." Id.

36. See Frye, 132 S. Ct. at 1410-11 ("The Court of Appeals erred . . . in articulating the precise standard for prejudice in this context. As noted, a defendant in Frye's position must show not only a reasonable probability that he would have accepted the lapsed plea but also a reasonable probability that the prosecutor would have adhered to the agreement and that it would have been accepted by the trial court."); Lafler, 132 S. Ct. at 1391 (holding that the district court and the Court of Appeals erred by ordering specific performance of the agreement the petitioner would have entered if he had received adequate advice).

37. Lafler, 132 S. Ct. at 1391 (Scalia, J., dissenting). 
than any other legal system in the world." Second, this system "subjects defense attorneys to serious temptations to disregard their clients' interests." And third, this system "makes it impossible to determine whether defendants have received the effective assistance of counsel." 38 Decisions like Lafler and Frye can neither guarantee effective legal representation in the plea negotiation process nor do much to make it more likely.

Defenses of plea negotiation offer sweet pictures of wellinformed defendants making rational assessments of surrender and gain. ${ }^{39}$ They depend on the assumption that defendants will be well represented. For private attorneys, however, a guilty plea is a quick buck. Defense attorneys have good reasons for collecting their fees in advance, and once they have pocketed their fees, their personal interests lie in disposing of their cases as rapidly as possible. This conflict of interest influences even well-paid, conscientious lawyers, and the bar includes some lawyers who are neither well paid nor conscientious. They handle a high volume of cases for small fees and almost never take a case to trial. ${ }^{40}$

Plea negotiation also minimizes work and reduces conflict within what organizational theorists call the "courtroom workgroup."1 Bargaining promotes cordial and comfortable relationships with prosecutors and judges. These interests may influence public defenders even more than they do private lawyers. ${ }^{42}$

Advising a client to enter a plea agreement can never be proven wrong. Taking a case to trial and losing may appear to have been a bad choice, especially when this decision has produced a sentence two or twenty times more severe than the one the prosecutor offered before trial. A bad outcome at trial may cause both the client's regard for his lawyer and the lawyer's self-esteem to suf-

38. Albert W. Alschuler, Personal Failure, Institutional Failure, and the Sixth Amendment, 14 N.Y.U. REv. L. \& Soc. ChANGe 149, 156 (1986).

39. See, e.g., Brady v. United States, 397 U.S. 742 (1970); McMann v. Richardson, 397 U.S. 759 (1970); Thomas W. Church, In Defense of "Bargain Justice", 13 LAW \& Soc'Y REV. 509 (1979); Robert E. Scott \& William J. Stuntz, Plea Bargaining as Contract, 101 YaLE L.J. 1909 (1992); Frank H. Easterbrook, Plea Bargaining as Compromise, 101 YALE L.J. 1969 (1992).

40. See Albert W. Alschuler, The Defense Attorney's Role in Plea Bargaining, 84 YalE L.J. 1179, 1181-1206 (1975).

41. See, e.g., LaWrence Baum, American Courts: Process ANd Policy 192 (2d ed. 1990); Stephanos Bibas, The Machinery of Criminal Justice 31 (2012); James Eisenstein \& HeRBert JACOB, Felony Justice: An ORganizational ANALYSiS OF

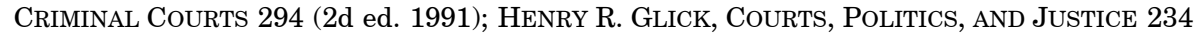

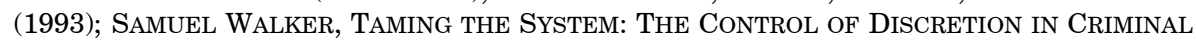
JUSTICE, 1950-1990 at 87 (1993).

42. See Alschuler, supra note 40 , at $1206-55$. 
fer. It also may increase the likelihood of a claim of professional ineffectiveness. When one has entered a plea agreement, however, he can always imagine that the outcome of a trial would have been worse. Advising a client to plead guilty is nearly always the safe, secure, comfortable, and profitable course. Everything in our criminal justice system pushes in that direction.

A lawyer's conferences with his client are not public, and neither are his bargaining sessions with the prosecutor. The effectiveness of Lafler and Frye depend on the willingness of lawyers to acknowledge failings so serious that their conduct falls below what the Supreme Court calls "the wide range of reasonable professional assistance." ${ }^{33}$ The lawyers whose performances were judged ineffective in Lafler and Frye were appropriately forthcoming, ${ }^{44}$ but when a defendant says, "my lawyer never told me about the offer," and the lawyer says, "oh yes I did," the defendant is almost

43. See Strickland v. Washington, 466 U.S. 668, 689 (1984) ("A court must indulge a strong presumption that counsel's conduct falls within the wide range of reasonable professional assistance.")

44. In Frye,

[t]rial counsel testified at the post-conviction hearing that trial counsel could not recall whether he had communicated the Offer to Frye. Trial counsel testified that there was no correspondence in his file to indicate any effort was made by his office to mail the Offer to Frye. Trial counsel could not recall speaking with, seeing, or ever attempting to contact Frye during the Offer window of November 15, 2007, to December 28, 2007.

Frye v. State, 311 S.W.3d 350, 352 (Mo. Ct. App. 2010), vacated and remanded, 132 S. Ct. 1399 (2012).

In Lafler, counsel testified that he advised his client to reject the prosecutor's offer because the charge of which the client later was convicted "could not be supported by the evidence." Counsel earlier had prompted the prosecutor to withdraw his offer by saying on the record of a pretrial conference that there was "insufficient evidence" and that the "Prosecution does not have the evidence to try to [sic] this case." See Cooper v. Lafler, 376 Fed. Appx. 563, 566, 2010 U.S. App. LEXIS 95899 (6th Cir. 2010), vacated and remanded, $132 \mathrm{~S}$. Ct. 1376 (2012). The Supreme Court said in Lafler that it was unclear whether respondent's counsel believed respondent could not be convicted for assault with intent to murder as a matter of law because the shots hit Mundy below the waist, or whether he simply thought this would be a persuasive argument to make to the jury to show lack of specific intent. And ... an erroneous strategic prediction about the outcome of a trial is not necessarily deficient performance. Here, however, the fact of deficient performance has been conceded by all the parties $\ldots . .$. T $]$ here is no need to address that question.

132 S. Ct. at $1390-91$.

The lawyers whose performances were judged ineffective in Lafler and Frye probably were not among those whose performance should prompt the most serious concern. Not only were these lawyers forthright about their errors; at least one of them was willing to try his cases. (The defendant in Frye ultimately pleaded guilty without a bargain.) If the defendant's lawyer in Lafler had taken the easy course and advised his client to plead guilty, his conduct would not have been judged ineffective. 
certain to lose. When a defendant claims that his lawyer misinformed him, many lawyers are likely to respond that the defendant misunderstood.

Moreover, the confessions of lawyers must be of a particular kind. Failing to convey critical information (say, about the existence of an offer) may entitle a client to relief, and negligent misstatements of law or fact may too. ${ }^{45}$ So may ignoring or failing to investigate important evidence, trading the interests of one client for the interests of another, and refusing to bargain at all in a case offering little or no chance of success at trial. ${ }^{46}$ Self-interested advice to plead guilty, inept negotiating, and erroneous predictions, however, almost certainly will not suffice. In our lawyersupportive legal system, no one need recognize the ineffectiveness of the weakest members of the bar, not even the weak lawyers themselves. One can always conjure up plausible reasons for a default. ${ }^{47}$

A prosecutor in Ventura County, California recalled the telephone calls he received from a lawyer who invariably persuaded his clients to plead guilty. "Phil," this lawyer would say, "will you let my guy go with a misdemeanor? Of course we'll plead anyway, but I just wondered if you could let him go with a misdemeanor." The prosecutor always answered that he could not reduce the charge "in view of the circumstances of the case." 48 Although the lawyer described by this prosecutor pocketed his clients' cash without helping them, Lafler and Frye will not touch him. Judicial decisions cannot significantly ameliorate the problem of defective, self-interested lawyering in the plea-negotiation process.

45. Some lawyers go to the point of lying to their clients in order to persuade them to plead guilty. A few even extract additional payments by claiming falsely that "the fix is in." See Alschuler, supra note 40, at 1194-97. A lawyer willing to lie to his clients, however, probably is willing to lie about lying.

46. See Rishi Batra, Lafler and Frye: A New Constitutional Standard for Negotiation, 14 CARDOZO J. CONFLICT RES. 309, 325-31 (2013).

47. Cf. Frye, 132 S. Ct. at 1408 ("Bargaining is, by its nature, defined to a substantial degree by personal style. The alternative courses and tactics in negotiation are so individual that it may be neither prudent nor practicable to try to elaborate or define detailed standards for the proper discharge of defense counsel's participation in the process.").

48. Conversation with Phillip E. Johnson sometime. 


\section{The AlCHEMY OF AMERICAN TRIALS: TURNING GOLD INTO LEAD}

\section{A. Finding a Baseline}

American defendants plead guilty in overwhelming numbers ${ }^{49}$ because the sentences imposed pursuant to plea agreements are substantially less severe than those imposed following convictions at trial. ${ }^{50}$ Defenders of plea negotiation typically treat post-trial sentences as the baseline from which plea agreements are to be judged. They (and many critics) view plea-bargained sentences as departures from an ethical norm. ${ }^{51}$ Justice Scalia's dissent in Lafler describes plea negotiation as a way to "beat the house, that is, to serve less time than the law says [an offender] deserves." 52

Justice Kennedy's majority opinion in Lafler rejects the assumption that post-trial sentences are an appropriate ethical baseline. He quotes Professor Bibas: “The expected post-trial sentence is imposed in only a few percent of cases. It is like the sticker price for cars: only an ignorant, ill-advised consumer would view full price as the norm and anything less a bargain." 53 Justice Kennedy reiterates the point in Frye, this time quoting Professor Barkow: "'[Defendants] who do take their case to trial and lose receive longer sentences than even Congress or the prosecutor might think appropriate, because the longer sentences exist on the

49. See Frye, 132 S. Ct. at 1407 (noting that "ninety-seven percent of federal convictions and ninety-four percent of state convictions are the result of guilty pleas") (citing DEPT. OF Justice, Bureau of Justice Statistics, Sourcebook of CRiminal Justice Statistics ONLINE, Table 5.22.2009, http://www.albany.edu/sourcebook/pdf/t5222009.pdf and DEPT. OF Justice, Bureau of Justice Statistics, S. Rosenmerkel, M. Durose, \& D. Farole, Felony Sentences In State CourTs, 2006-Statistical Tables, p. 1 (NCJ226846, rev. Nov. 2010), http://bjs.ojp.usdoj.gov/content/publ/pdf/fssc06st.pdf).

50. See, e.g., Albert W. Alschuler, The Changing Plea Bargaining Debate, 69 CALIF. L. REV. 652, 653-57 (1981).

51. For example, Thomas W. Church's defense of plea bargaining recognizes that "bargaining, particularly when the judge or prosecutor manipulates post trial sentencing philosophy sentences to 'punish' those who refuse to plead guilty, can operate to coerce or unfairly encourage guilty pleas." Church, supra note 39, at 519. In a "defensible plea bargaining system," Church says,

those cases that go to trial must be decided on the merits, without penalizing the defendant for not pleading guilty. In other words, trial sentences must be objectively deserved according to whatever is embodied in the penal code. Plea bargaining should therefore result in sentences Id. at 520 . less than this theoretically correct sentence.

52. Lafler v. Cooper, 132 S. Ct. 1376, 1398 (2012) (Scalia, J., dissenting).

53. Id. at 1387 (quoting Stephanos Bibas, Regulating the Plea-Bargaining Market: From Caveat Emptor to Consumer Protection, 99 CAL. L. REV. 1117, 1138 (2011)). 
books largely for bargaining purposes." 54 If accurate, the observations of Professors Bibas and Barkow rout the central claim of the dissenters - that "a full dress criminal trial" is the "exorbitant gold standard of American justice" ${ }^{" 55}$ _and the dissenters offer no reply.

Shortly after endorsing the Bibas and Barkow observations, however, the Frye majority disregards their implications. Justice Kennedy writes, "To note the prevalence of plea bargaining is not to criticize it. The potential to conserve valuable resources and for defendants to admit their crimes and receive more favorable terms at sentencing means that a plea agreement can benefit both parties. $" 56$

If post-trial sentences are unjust and are imposed simply for the purpose of inducing guilty pleas (as the Supreme Court recognizes five-to-four), plea bargaining surely merits criticism. This process then benefits both parties only in the sense that a gunman's demand for your money or your life benefits you as well as the gunman. Compared to death at the hands of the gunman, "your money or your life" is a great offer. Proposals commonly are treated as coercive, however-as "threats" rather than "offers"-when refusing them would leave recipients worse off than they ought to be. ${ }^{57}$

54. Frye, 132 S. Ct. at 1407 (quoting Rachel E. Barkow, Separation of Powers and the Criminal Law, 58 STAN. L. REv. 989, 1034 (2006)). Bibas's remark can be read as saying only that the sentences imposed following trials depart from the statistical norm (something that no one would deny). Barkow's statement says more clearly that these sentences (or many of them) depart from an ethical norm as well.

55. Lafler, 132 S. Ct. at 1398 (Scalia, J., dissenting).

56. Id. at 1407 (majority opinion).

57. See Alan Wertheimer, CoERCION passim (1987); Albert W. Alschuler, Constraint and Confession, 74 DENVER U.L. REV. 957, 962-67 (1997) (reviewing several approaches to defining coercion and explaining why the better ones focus on the wrongfulness of proposals rather than the supposedly overborne wills of the people receiving them). See generally Scott Anderson, Coercion, in STANFoRd EnCyClopedia of PHILOSOPHY (Edward N. Zalta, ed., Winter 2011), http://plato.stanford.edu/entries/coercion/\#ThrBas.

Although distinguishing between rewards and penalties makes sense in many contexts, I have argued that officials should employ neither penalties nor rewards to induce confessions or pleas of guilty. See Alschuler, supra note 57, at 967-69. The common law took the same position, declaring that a guilty plea or confession induced by either a promise or a threat was involuntary. See, e.g., Rex v. Warickshall, 168 Eng. Rep. 234 (Cr. Cas. 1783) (holding a confession obtained "by promise of favour" inadmissible); Hopt v. Utah, 110 U.S. 574, 584 (1884) (declaring that a confession must be "uninfluenced by hope of reward or fear of punishment"); Wilson v. United States, 162 U.S. 613, 622 (1896) (declaring a confession "inadmissible if made under any threat, promise, or encouragement of any hope or favor"); Bram v. United States, 168 U.S. 532, 542-43 (1897) (declaring that a confession may not be received in evidence unless it is "free and voluntary; that is, must not be extracted by any sort of threats or violence, nor obtained by any direct or implied promises, however slight"). 
Choosing the appropriate ethical baseline is not simply a matter of perspective, and, when one seriously examines our criminal justice system, Bibas, Barkow, and the Lafler-Frye majority appear to have it right. Before I explain why, however, it seems appropriate to consider the suggestion of a participant in this symposium that plea bargains really aren't bargains at all.

\section{B. An Unconvincing Study}

On one point, David Abrams' empirical findings match almost everyone else's. He reports that the sentences imposed following convictions at trial are substantially more severe than those imposed following pleas of guilty. ${ }^{58}$ Abrams maintains, however, that this frequently repeated finding answers the wrong question.

In Abrams' view, earlier studies erred by considering only defendants who were convicted by guilty plea or at trial. ${ }^{59}$ His study includes acquitted defendants as well. It treats the sentences of these defendants as zero. With these "sentences" of zero included in the mix of post-trial sentences, the post-trial sentences no longer appear to be more severe than those imposed following guilty pleas. To the contrary, they appear to be much less severe. ${ }^{60}$ As a group, defendants who have taken their cases to trial appear to have achieved better results than those who have pleaded guilty. ${ }^{61}$

Abrams does not spell out what lesson he would draw from this finding, but he seems to suggest that plea bargains are usually bad deals for defendants. A risk-neutral defendant who discounts his probable post-conviction sentence by the likelihood of acquittal and compares it to the prosecutor's offer should usually reject the offer and go to trial. This defendant then will either win big or

58. David S. Abrams, Is Pleading Really a Bargain?, 8 J. EMPIRICAL LEGAL STUD. 200, 209 (2011).

59. See id. at 202-03.

60. See id. at 209. The reason why prior sentencing studies focused on convicted rather than acquitted defendants is not difficult to discern. A finding that some offenders received more severe sentences than other, equally culpable offenders only because they exercised their right to trial may be cause for concern. A finding that offenders received more severe sentences than non-offenders, however, is cause for celebration, not concern. This finding is also unsurprising.

61. When Abrams regressed on variables like age, race, sex, and type of offense, the correlation he found between insisting on trial and receiving a less severe sentence remained strong. I summarize Abrams' central finding by saying that, as a group, defendants who stood trial received less severe sentences than defendants who pleaded guilty, but one could also say things like, "As a group, young white men who stood trial for weapons offenses received less severe sentences than young white men who pleaded guilty to weapons offenses." Disaggregation of this sort would not affect the analysis that follows. 
lose big, but insisting on trial will on balance reduce his expected punishment. $^{62}$

For reasons I will explain shortly, I do not credit Abrams' principal finding. ${ }^{63}$ Even if I accepted this finding, however, I would not draw the lesson Abrams invites readers to draw. The discovery that defendants who went to trial achieved better results as a group than defendants who pleaded guilty does not show that any defendant in either group miscalculated. This finding may indicate only that plea bargains were good deals for defendants who took them and bad deals for those who didn't.

Every defendant in Abrams' sample who was acquitted might have discounted his expected post-trial sentence by the likelihood of acquittal and might have matched this discounted sentence against the prosecutor's offer, and every one of them might have made the correct choice. Every defendant who pleaded guilty also might have discounted the expected post-trial sentence by the likelihood of acquittal, and every one of them might have made the correct choice as well. ${ }^{64}$

Imagine, for example, a jurisdiction with a marvelous public defender system, the County of Dershowitz. Capably advised defendants in Dershowitz accept only offers that are truly in their interests. The District Attorney of Dershowtiz, however, is perverse. One day, he charges ten thousand men of Harvard with mayhem simply because a near-sighted witness, Magoo, reported seeing these men covered in crimson. The ten thousand men of Harvard demand trials, and all of them are acquitted. Abrams records their sentences as zero, and ten thousand sentences of zero bring the mean post-trial sentence to a tiny fraction of the mean

62. Abrams embraced this thesis more clearly in the abstract of his article than in the article itself:

Conventional wisdom suggests that defendants are better served by entering into a plea bargain, to avoid what is known as the "trial penalty." In this article I present evidence that this notion is likely mistaken. In OLS regressions using data from Cook County state courts, I find that a risk-neutral defendant seeking to minimize his or her expected sentence would do substantially better by rejecting a plea bargain. I also employ an IV approach to the question and, while the instrument is weak, the results are consistent with the OLS: defendants are better off going to trial.

Abrams, supra note 58, at 200 (abstract).

63. Many of the defendants whom Abrams described as standing trial did not in fact stand trial. See text at notes 65-74 infra.

64. The defendants who were convicted at trial and received more severe sentences than those in the two other groups can be said in retrospect to have made erroneous choices, but even they might have made appropriate judgments (or bets) ex ante. 
post-guilty-plea sentence. The existence of ten thousand wrongly accused Harvard men, however, reveals nothing about the wisdom of the choices made by the ably advised defendants who pleaded guilty before the district attorney went berserk. It also reveals nothing about the wisdom of the many defendants who are scheduled to plead guilty in Dershowitz tomorrow. The agreements these defendants entered with the district attorney may indeed have been bargains.

In any event, Abrams does not convince me that, with acquittals included, post-trial sentences are less severe than post-plea sentences. Abrams studied official court data from Cook County, Illinois- "a data set containing 42,552 cases initiated between 1997 and 2001 that were completed by the end of 2004." ${ }^{65}$ Because more than 40,000 felony cases were resolved annually in the Circuit Court of Cook County during this period, ${ }^{66}$ the data set does not appear to include all of the cases that began and ended within the study period. Indeed, Abrams acknowledged in his presentation at this symposium that his data set did not include all cases. ${ }^{67}$ Abrams also did not reveal whether the data included misdemeanor as well as felony cases, but they seem to consist almost entirely of felony cases.

Most of Abrams' study is presented in the obscure language of empirical economists, but I believe I understand Table $2 .{ }^{68}$ This table divides defendants into those who pleaded guilty and those who stood trial. One column then reveals what proportion of defendants in various offense categories were convicted.

It comes as no surprise that $100 \%$ of the defendants who pleaded guilty were convicted, but the percentage of convicted defendants in the group that stood trial could raise eyebrows. Abrams reports conviction rates of $50 \%$ for defendants tried on drug possession charges, $48 \%$ for those tried on drug distribution charges, $36 \%$ for those tried on weapons charges, $47 \%$ for those tried on

65. Abrams, supra note 58, at 208.

66. See, e.g., ANNUAL RePORT OF the Illinois Courts, Statistical Summary 2001, Caseload and Statistical Records, Felony Dispositions and Sentences by County Circuit Courts of Illinois, Calendar Year 2001 (hereinafter "ANNUAL REPORT"), http://www.state.il.us/court/supremecourt/AnnualReport/2001/StatsSumm/pdf/cir_caseload \&stat.pdf (reporting that 42,453 defendants were charged with felonies in the Circuit Court of Cook County during calendar year 2001).

67. Beyond mentioning that all of the study cases were resolved at one Cook County courthouse (2600 South California Avenue), Abrams did not indicate how the data set was compiled.

68. See Abrams, supra note 58, at 212 tbl. 2. 
theft charges, $53 \%$ for those tried on burglary charges, $43 \%$ for those tried on robbery charges, $47 \%$ for those tried on car theft charges, and $55 \%$ for those tried on charges of assault and battery. In most offense categories, more defendants appear to have been acquitted than convicted. In no offense category did the conviction rate exceed $55 \%$, and in one category it was only $36 \% .{ }^{69}$

Abrams evidently included a large number of sentences of zero in his mix of post-trial sentences. Although he did not supply the number, it seems a reasonable guess that roughly half of the sentences in his post-trial mix were sentences of zero. It was as though the 10,000 wrongly accused men of Harvard had marched from the County of Dershowitz to the County of Cook.

I have lived in Cook County; I have practiced and taught law in Cook County; I have studied Cook County; and Professor Abrams' Cook County is not the one I know. Statistics included in the $A n$ nual Report of the Illinois Courts permit one to calculate the conviction rates in felony cases tried in Cook County in 2001, a year that was both typical and included in Abrams' study period. In that year, $75 \%$ of the 301 felony defendants tried by juries and $81 \%$ of the 10,996 felony defendants tried by judges were convicted. ${ }^{70}$ These conviction rates are similar to those reported by other American jurisdictions. ${ }^{71}$

The disparity between the normal Cook County conviction rates reported by the Illinois courts and the surprisingly low conviction rates reported by Abrams is apparently explained by the fact that Abrams treated all defendants whose cases ended without conviction as though they had been acquitted. Abrams in fact acknowledged during his presentation at this symposium that many of the defendants whom his article described as "acquitted at trial" were not acquitted at trial at all.

The Annual Report of the Illinois Courts includes a catchall category of terminated cases called "remaining balance." This category "includes such dispositions as transfers to inactive/fugitive warrant calendar, extradition proceedings, and dismissed on motion of state." The number of cases in this category in Cook Coun-

69. Id.

70. See ANNUAL RePORT, supra note 66.

71. See, e.g., Neil Vidmar, Sara Sun Beale, Mary Rose, \& Laura F. Donnelly, Should We Rush to Reform the Criminal Jury?: Consider Conviction Rate Data, 80 JuDICATURE 286, 287-89 (1997) (reporting jury trial conviction rates in felony cases of $68.3 \%$ in North Carolina, $58.9 \%$ in Florida, $82.1 \%$ in California, $84 \%$ in Texas, $72.3 \%$ in New York State, and more than $80 \%$ in both drug and non-drug cases in the federal courts). 
ty in 2001 dwarfed the number of acquittals at trial, 7,848 to 2,134 . When the "remaining balance" cases are treated as acquittals or "non-convictions," Cook County's overall conviction rate in cases not resolved by guilty pleas drops to a rate resembling those that Abrams reported, $48 \% .^{72}$

Abrams' study thus reveals that defendants who abscond receive lower sentences than defendants who plead guilty-that is, until they are caught. It also teaches us that extradited defendants receive lower sentences than defendants who plead guiltythat is, until they are tried in the jurisdictions to which they are sent. And it reminds lawyers never to urge clients to enter plea agreements when prosecutors are willing to dismiss their cases outright. ${ }^{73}$

The low conviction rates Abrams reported enabled him to place a large number of sentences of zero in the cauldron of sentences imposed following trials. This number was not typical of the American criminal justice system or even of Cook County. Abrams' study does not provide convincing evidence that defendants who stand trial generally achieve better results than those who plead guilty, and even if it did, it would not show that any of the defendants who entered plea agreements had been snookered..$^{74}$

\section{The Expected Difference Between Sentences Imposed Following Trials and Those Imposed Following Guilty Pleas}

Consider what offers and agreements should look like in a pleabargaining system that does only what bargaining prosecutors and defense attorneys acknowledge (and boast) that they do. Viewing offers and agreements from this perspective will lead to a

72. ANNUAL REPORT, supra note 66.

73. Some dismissals occur after defendants have refused to enter plea agreements. For example, a prosecutor might have offered to permit a guilty plea to a misdemeanor in exchange for the dismissal of a motion to suppress evidence. The defendant might have declined the prosecutor's offer and prevailed on the motion to suppress. With critical evidence suppressed, the prosecutor then might have dismissed the case. Other dismissals, however, occur because prosecutors recognize that their cases should never have been filed. An effort to determine whether "a plea is a bargain" should not include dismissals in the comparison group without differentiating among dismissals.

74. Abrams noted at the symposium that his findings were robust. He was confident that had he actually compared post-trial sentences to post-guilty-plea sentences, the posttrial sentences would have been less severe. Abrams might be correct, and it would be worth the effort to find out. The following section of this article considers circumstances that might explain findings like Abrams' if these findings were replicated in a better conceived and better executed study. 
few additional remarks about what might account for findings like David Abrams'.

Prosecutors readily acknowledge engaging in both "odds bargaining" and "costs bargaining." 75 That is, they offer lower sentences in exchange for guilty pleas both to eliminate the risk of acquittal at trial and to avoid the cost of trials. ${ }^{76}$ A prosecutor who engaged only in odds bargaining might estimate the likelihood of a defendant's conviction at trial at 50\% and the defendant's probable sentence if convicted at trial at ten years. The prosecutor then might offer the defendant a sentence of five years in exchange for his plea. Prosecutors sometimes quote the line, "Half a loaf is better than none."

To be sure, this illustration is oversimplified. For most defendants, the first year of a prison term has greater disutility than the last, and part of an offender's punishment consists, not of imprisonment, but of the stigmatization and disabilities that follow conviction. Sophisticated bargainers take account of these consequences and others, but the simplified illustration suffices here.

I have cast students in their first week of law school as prosecutors instructed by a superior to bargain with the sole goal of obtaining the most punishment they can for every taxpayer dollar expended. ${ }^{77}$ I then have asked them to consider what their last, best offer would be to a defendant whose likelihood of conviction at trial was $50 \%$ and who faced ten years of imprisonment if convicted. After a student has proposed a five-year offer, I have asked whether other students would increase or decrease it. Students invariably have struggled to justify lesser discounts from the predicted ten-year post-trial sentence. It typically has taken some cajolery on my part to prompt a student to give the correct answer from an economic or "bangs for the buck" perspective: the discount should be greater.

On the simplified assumptions noted above, a five-year offer would leave a risk-neutral defendant indifferent to the choice between guilty plea and trial. ${ }^{78}$ A cost-conserving prosecutor, how-

75. I owe this terminology to Paul Schectman.

76. See Albert W. Alschuler, The Prosecutor's Role in Plea Bargaining, 36 U. CHI. L. REV. 50, 52-85 (1968).

77. See Frank H. Easterbrook, Criminal Procedure as a Market System, 12 J. LEGAL STUD. 289, 289 (1983) ("I argue in this essay that the aspects of criminal procedure treated with the greatest skepticism by academics and the popular press - prosecutorial discretion, plea bargaining, and sentencing discretion - may be understood as elements of a wellfunctioning market system.") (internal citations omitted).

78. The assumption of risk neutrality is a further oversimplification: 
ever, does not want the defendant to be indifferent. He hopes to avoid a trial and is prepared to engage in costs bargaining as well as odds bargaining. The prosecutor therefore tailors his offer, not to balance, but to overbalance the defendant's chances of acquittal. The prosecutor's final offer might be four years, three or two. It might be influenced by how much he expects a trial to cost.

If defendants faced the same costs as prosecutors and were equally concerned to avoid them, costs bargaining would disappear from the calculus. Defendants, however, are not equally concerned to minimize costs. About $80 \%$ are indigent and are represented by public defenders or other appointed attorneys. ${ }^{79}$ They do not pay the costs of trials, ${ }^{80}$ and, at least in theory, their lawyers focus only on their interests, not the taxpayers'.

Defendants represented by private attorneys do pay some of the costs of trial, and the prospect of higher legal fees can influence them to plead guilty. ${ }^{81}$ Because limiting criminal punishment ranks highly on most defendants' utility curves, however, they are not inclined to be frugal. "It's like buying a casket," one lawyer reported. "They're not worried about how much it costs-until later." ${ }^{2}$ Because cost concerns are asymmetrical, defendants should engage mostly in odds bargaining while prosecutors engage in both odds bargaining and costs bargaining. Agreement should

\footnotetext{
One of the commodities that the representatives of the state "sell" during pretrial negotiations is certainty. During the period between arrest and trial, most defendants experience a great and understandable anxiety about what will happen to them. The promise that a prosecutor or trial judge offers in a bargaining session usually provides the first authoritative answer to that question that a defendant can secure. A trial, by contrast, represents what Oakland Public Defender John D. Nunes called "a plunge from an unknown height.". . [T] [Te reduction of anxiety-the minimization of grab-bag uncertainty—is itself a value to many defendants.
}

Albert W. Alschuler, The Trial Judge's Role in Plea Bargaining, 76 ColuM. L. REv. 1059, 1080-81 (1976).

79. Steven K. Smith \& Carol J. DeFrances, Bureau of Justice Statistics SELECTED FINDINGS: INDIGENT DEFENSE 4 (1996), available at http://bjs.gov/content/pub/pdf/id.pdf (reporting the percentage of felony defendants with appointed attorneys in America's 75 largest counties).

80. Again, I oversimplify. The costs of trial include time and anxiety as well as money, and non-monetary costs can influence plea negotiations.

81. See Scott Shane, From Spy to Source to Convict, N.Y. TimES, Jan. 6, 2013, at A1 (Former C.I.A. agent John Kiriakou "said he had paid his defense lawyers more than $\$ 100,000$ and still owed them $\$ 500,000$; the specter of additional, bankrupting legal fees, along with the risk of a far longer prison term that could separate him from his wife and children for a decade or more, prompted him to take the plea offer ....").

82. Jackson B. Battle, In Search of the Adversary System: The Cooperative Practices of Private Criminal Defense Attorneys, 50 TEX. L. REV. 60, 111 (1971). 
come only when the prosecutor has made an offer that overbalances the defendant's chances of acquittal.

When a defendant is certain to be acquitted at trial, the prosecutor cannot make an offer that will overbalance his chances of acquittal, ${ }^{83}$ but in almost every other case, he can. The prosecutor can get the most punishment for the government's bucks by making such an offer, and the defendant can reduce his expected punishment by accepting it. Does it follow that, in a system of costs bargaining and odds bargaining, there should be no trials? Do cases go to trial only when defendants are so convinced of their innocence, so indignant about prosecutorial overreaching, or so ashamed to admit their guilt that they press their luck irrationally? Many cases do go to trial for those reasons, but the answer is probably no.

Even when both parties engage only in costs bargaining and odds bargaining, they may disagree about circumstances that influence the bargaining calculus: what post-trial sentence is likely, what subjective disutility (or suffering) various punishments are likely to impose, what a trial is likely to cost, and, perhaps most importantly, what chance the defendant has of winning at trial. The differences in the parties' estimates may prevent an agreement.

For example, although the prosecutor and defense attorney might both estimate the defendant's probable post-trial sentence at ten years, the prosecutor might believe that the likelihood of conviction is $90 \%$ while the defense attorney might estimate it at $50 \%$. The prosecutor then might conclude that agreeing to anything less than, say, an eight-year-sentence would not be costeffective, while the defendant, advised by his attorney, might conclude that any sentence of five years or more would not minimize his expected punishment. The parties would be unlikely to reach an agreement.

Lawyers who generally adhere to the economic model described above may depart from it sometimes. For example, a prosecutor might fear that the public would disapprove his offer of a light sentence in a publicized case. (The public seems not to understand how, in a regime of odds bargaining, the offer of a seemingly ludicrous sentence can advance its interests.) Or the prosecutor

83. Again, I abstract from the "process costs" of trial. See Albert W. Alschuler, Implementing the Criminal Defendant's Right to Trial: Alternatives to the Plea Bargaining System, 50 U. CHI. L. REV. 931, 949-52 (1983). 
might wish to gain trial experience, try a case against a noted defense attorney, or seek fame and political fortune by trying a front-page case. Similarly, a defense attorney might conclude that trying a prominent case will be good advertising. ${ }^{84}$

Some prosecutors and defense attorneys toss the economic model to the winds. One prosecutor declared,

When I sit down with a defense attorney who knows how to be reasonable, we judge the whole man. Neither of us cares what evidence would be admissible and what would not, or which one of us would win at trial. We simply try to do the fair thing with each case. ${ }^{85}$

Frequent departures from the economic model occur because, as noted above, the personal interests of defense attorneys encourage them to recommend guilty pleas to their clients. ${ }^{86}$ A prosecutor need not offer a sentence that will overbalance the defendant's chances of acquittal when the defense attorney does not insist on such an offer and back his demand with a credible threat of trial.

When defense attorneys sell out their clients too cheaply, findings like those reported by David Abrams should come as no surprise. ${ }^{87}$ As a group, defendants who plead guilty may obtain less favorable outcomes than those who stand trial because many of them are represented by lawyers who do not press hard for the offers that economic theory says prosecutors should make.

At the same time, a lawyer who demands an offer minimizing his client's expected punishment may not get it, for prosecutors may be the ones who forsake the economic model. Like my firstyear law students, they may recoil from placing the greatest pressure to plead guilty on defendants who may be innocent and/or from offering sentences far lighter than they believe honest-to-God offenders deserve. Although these prosecutors may engage in odds bargaining, they may not take the process to its logical conclusion. When prosecutors refuse in some cases to make offers that overbalance the defendants' chances of acquittal, the defendants in these cases will, as a group, achieve better results by in-

84. For a more sophisticated and complete examination of why plea-bargaining reality often bears little resemblance to the economic model, see Stephanos Bibas, Plea Bargaining Outside the Shadow of Trial, 117 HARV. L. REV. 2463 (2004).

85. Alschuler, supra note 76 , at 54 .

86. See text at notes 37-43 supra.

87. See text at notes 59-61 supra. 
sisting on trial. There may be enough of them to produce findings like those Abrams reported.

To reiterate, departures from the economic model by either prosecutors or defense attorneys could produce findings like those of David Abrams. Findings like his, however, do not conclusively establish any departure from the model. In the small minority of cases that go to trial, negotiators may differ in their estimates of the likelihood of conviction and/or other circumstances affecting the bargaining calculus, and the predictions of defendants and their lawyers generally may be better than those of prosecutors. ${ }^{88}$

\section{A Hard Look at the Post-Trial Baseline}

As noted above, Justice Scalia and the other Lafler-Frye dissenters view plea bargaining as a way for an offender to "to serve less time than the law says he deserves." ${ }^{89}$ Justice Kennedy and the other justices in the Lafler-Frye majority reply that the sentences imposed following conviction at trial often are undeserved. Many of these sentences are more severe "than even Congress or the prosecutor might think appropriate, because the longer sentences exist on the books largely for bargaining purposes." 90 Although the majority praises plea bargaining as beneficial to both parties, its recognition that post-trial sentences often are imposed to gain bargaining leverage makes the process indefensibledifferent in degree but not in principle from the transaction proposed by a gunman who demands your money or your life. ${ }^{91}$

Here is a multiple-choice question. Which of the following six propositions best captures your view of the partly empirical, partly conceptual issue that divided the majority and dissenting justices:

88. I do not consider this last hypothesis particularly likely. To the contrary, information asymmetries suggest that prosecutors should have the edge in estimating probable trial outcomes. Although defendants know better than prosecutors whether they are guilty or innocent, this information might not make them better predictors. Indeed, an unwillingness to face the fact that juries sometimes convict the innocent could distort an innocent defendant's predictions. Lawyers generally regard both innocent and guilty defendants as too optimistic about their prospects at trial. See BIBAS, supra note 41, at 55. Moreover, professional estimates of trial outcomes are likely to be superior to amateur estimates, and unlike defense attorneys, prosecutors need not respect the wishes of amateur clients. Prosecutors are likely to know more than defendants and their lawyers about the most important determinant of trial outcomes, the strength or weakness of their evidence.

89. Lafler v. Cooper, 132 S. Ct. 1376, 1398 (2012) (Scalia, J., dissenting).

90. Missouri v. Frye, 132 S. Ct. 1399, 1407 (2012) (quoting Rachel E. Barkow, Separation of Powers and the Criminal Law, 58 STAN. L. REV. 989, 1034 (2006)).

91. See text at notes 53-57 supra. 
Does plea bargaining reward defendants who plead guilty or penalize those who stand trial?

A. An Incoherent Question. The concepts of harshness and leniency are relative and draw meaning only from each other. "If we are 'lenient' toward [defendants who plead guilty], we are by precisely the same token 'more severe' toward [those who plead not guilty]."92 Asking whether plea bargaining rewards defendants who plead guilty or penalizes defendants convicted at trial is incoherent. When bargaining does one thing, it also does the other.

B. An Unanswerable Question. Whether plea bargaining rewards defendants who plead guilty or penalizes defendants convicted at trial is a sensible query, but it is not a question that anyone can resolve. In principle, one can envision a "Goldilocks" or "just right" sentence-the sentence an offender deserves or the sentence that best accomplishes the law's forward-looking, crime-prevention purposes. If a defendant who pleads guilty receives a sentence less severe than the Goldilocks sentence, he is rewarded. Such a sentence may short-change the public, but it benefits him. At the same time, an offender who receives a sentence more severe than the Goldilocks sentence because he has stood trial is unfairly penalized. The constitutional right to trial means at a minimum that the government may not make standing trial a crime. On this view, the concepts of harshness and leniency need not be relative; they can describe deviations in opposite directions from a moral baseline. In practice, however, no one can identify the Goldilocks sentence, and no one can know whether plea bargaining rewards guilty pleas or penalizes exercise of the right to trial. It is as likely to be one thing as the other.

C. A Formalist Answer: The Law Deems Post-Trial Sentences Deserved. Although no one may know the Goldilocks sentence or what punishment an offender deserves, one

92. Scott v. United States, 419 F.2d 264, 278 (D.C. Cir. 1969); accord People v. Earegood, 162 N.W. 2d 802, 812 (Mich. Ct. App. 1968), rev'd in part, People v. Earegood, 173 N.W.2d 205 (Mich. 1970); Comment, The Influence of the Defendant's Plea on Judicial Determination of Sentencing, 66 YALE L.J. 204, 220 (1956). 
can easily determine what punishment the law says he deserves. This punishment is the one that sentencing authorities have determined should be imposed following a conviction at trial. ${ }^{93}$ Because no one is in a position to psychoanalyze the authorities or second-guess their official determinations, plea bargaining must be viewed as rewarding defendants who plead guilty. The issue is one of juridical theory, not fact.

D. One Realist Answer: Post-Trial Sentences are Imposed Because Offenders Deserve Them, While Defendants Who Plead Guilty are Rewarded. To judge whether plea bargaining rewards defendants who plead guilty or instead penalizes those convicted at trial, one need neither know the Goldilocks sentence nor indulge in the fiction that post-trial sentences must be considered deserved simply because officials have imposed them. After examining the actual motives of sentencing authorities, the likely motives of people in their situation, and the consequences of their choices, one can make a plausible guess about what punishments would be imposed in a regime without plea bargaining. If all defendants in a system without bargaining would receive the punishments now imposed on defendants convicted at trial, plea bargaining can fairly be said to reward those who plead guilty. These defendants achieve better results in a system with plea bargaining than they would in a system without it. At the same time, defendants who stand trial would be treated identically in both systems. And in fact, an examination of the American legal system indicates that it fits this pattern. Current post-trial sentences reflect bona fide determinations of desert and nothing else. In the absence of plea bargaining, these sentences probably would be imposed across the board.

E. An Opposing Realist Answer: Post-Trial Sentences are Inflated to Discourage Exercise of the Right to Trial. As suggested in the preceding answer (D), the appropriate inquiry is what sentences offenders would receive in a

93. See Lafler, 132 S. Ct. at 1398 (Scalia, J., dissenting) (declaring that plea bargaining gives defendants a opportunity "to serve less time than the law says [they] deserve[]."). But see text at notes 104-05 infra. 
system without plea bargaining. The correct response, however, is the opposite of the one that answer (D) supplies. For the most part, it is offenders who plead guilty who receive the sentences they are thought to deserve. The more severe sentences that follow conviction at trial are imposed, not to punish or deter crime, but to deter exercise of the right to trial. America's penology matches that of a Chicago trial judge who declared, "He takes some of my time, I take some of his. That's the way it works." 94

F. None of the Above. Please select this answer if you know the Goldilocks sentence.

Before giving your final answer to this multiple-choice question, consider another thought experiment. Imagine a hypothetical democracy called Becker in which, until recently, everyone embraced the penal philosophy of Jeremy Bentham. Everyone in Becker believed that the function of criminal punishment was deterrence and that penalties should be calculated to ensure that crime does not pay. ${ }^{95}$

Of course not every crime is detected. The people of Becker concluded that penalties should be determined by multiplying the gain an offender derived from committing his crime times the number of crimes he could have been expected to commit before being convicted. For several reasons, they also concluded that judges should not impose punishments much more severe than those provided by this calculus. First, more severe punishments would cause offenders to suffer needlessly, and "all punishment in itself is evil. . . . [I]f it ought at all to be admitted, it ought only to be admitted in as far as it promised to exclude some greater evil." 96 Second, imposing punishments more severe than necessary would waste public funds. And third, effective deterrence requires grading crimes and reserving more severe penalties for more severe crimes. If-like murderers-kidnappers, armed rob-

94. See Alschuler, supra note 78, at 1089 (describing the remark a Chicago judge made to Dallin H. Oaks after telling Oaks that, if his client declined an offer of two-to-five years and was convicted at trial, the judge would impose a sentence of twenty years).

95. See Gary S. Becker, Crime and Punishment: An Economic Approach, 76 J. PoL. Econ. 169, 169 (1968); William M. Landes, Optimal Sanctions for Antitrust Violations, 50 U. CHI. L. REV. 652 (1983).

96. Jeremy Bentham, An Introduction to the Principles of Morals and Legislation, in JEREMY BENTHAM AND JOHN STUART MILL, THE UTILITARIANS 162 (1961). 
bers, and rapists were subject to capital punishment, they might see no reason not to kill their victims.

For many years, Becker implemented its Benthamite penology without variation. The people of Becker recently realized, however, that practical necessity required them to discourage exercise of the right to trial. Judges then were instructed to impose more severe sentences following convictions at trial than following pleas of guilty. Moreover, they were told to make the difference so substantial that $95 \%$ of all offenders would plead guilty.

Social science research reveals that the new policy has been implemented. With every other relevant variable held constant, the sentences currently imposed following convictions at trial are much more severe than those imposed following pleas of guilty, and $95 \%$ of all convictions in Becker are by plea.

Here's the thought experiment. The judges could have complied with Becker's new policy either by lowering the sentences of defendants who pleaded guilty below the Benthamite baseline or by increasing the sentences of defendants convicted at trial above it. These judges are sane, smart, public-spirited people. Can you guess which they did?

Do you suppose that the judges of Becker reduced the sentences of defendants who pleaded guilty so that these sentences no longer overbalanced the benefit offenders derived from committing their crimes? Do you imagine that they—or that any polity—would create a regime in which crime does pay for $95 \%$ of all offenders? Or does it seem more likely that the judges of Becker still sentence the vast majority of criminals to the punishment needed to deter crime while imposing additional punishment on a tiny minority to save the cost of trials? ${ }^{97}$

Becker is only one of several hypothetical jurisdictions that recently rejected the judgment of the Framers of the U.S. Constitution that the cost of trials is worth paying. Each of these jurisdictions now sentences defendants who are convicted at trial more severely than those who plead guilty. The former penology of the other hypothetical jurisdictions, however, differed from the prior

97. Odds bargaining often could lead deterrence-minded authorities to impose sentences below the Benthamite baseline; some deterrence is better than none. The issue posed by the thought experiment, however, is how a deterrence-minded polity probably would accomplish the objectives of costs bargaining. Would it be more likely to impose sentences below the Benthamite baseline in 19 cases out of 20 or to impose a sentence above the baseline in one? Recall that lowering the baseline at all leaves crime a profitable enterprise. 
penology of Becker. Perform the same thought experiment with them.

When an offender was convicted in Kant, judges previously imposed the sentence he deserved. Do you suppose that judges in Kant now sentence $95 \%$ of all offenders less severely than they deserve? In Greenwood, judges formerly assessed the dangerousness of each offender and sentenced him to a long enough prison term to protect the public through incapacitation. Do you suppose the judges of Greenwood now decline to incapacitate the vast majority of offenders long enough to protect the public? In Wootton, judges formerly required offenders to undergo the treatment they believed the offenders needed to cure their socially harmful behavior. Do you suppose these judges now require $95 \%$ of all offenders to undergo only part of this treatment?

People devise rationalizations for their self-interested conduct. If the changes that occurred in Becker, Kant, Greenwood, and Wootton had happened more gradually, even the authors of these changes might not have realized just what they were doing. These legislatures, sentencing commissions, prosecutors, and judges might have been unwilling to sentence most offenders less severely than they deserved or to leave crime a paying proposition. Instead, they might have conserved public resources by sentencing offenders convicted at trial more severely. Officials might nevertheless proclaim (and even believe) that they never sentenced anyone more severely than he deserved or more than public protection required. ${ }^{98}$ Considering what officials would have done in a regime without plea bargaining may offer greater insight than asking what officials believe they are doing. ${ }^{99}$ Like everyone else, criminal justice officials can convince themselves of many things.

The thought experiment you just performed may have persuaded you that officials are more likely to pursue cost-saving objectives by penalizing exercise of the right to trial than by sacrificing the purposes of criminal punishment (at least in part) for $95 \%$ of

98. I have examined the claim that defendants who plead guilty deserve lighter sentences than those convicted at trial in Alschuler, supra note 50, at 661-69, 718-23.

99. Economists speak of "revealed preferences." They maintain that people's preferences are shown, not by what they say, but by what they do. See, e.g., Paul A. Samuelson, Consumption Theory in Terms of Revealed Preference, 15 EcONOMICA 243, 243 (1948); Hal R. Varian, Revealed Preference, in SAMUELSONIAN ECONOMICS AND THE TWENTY-FIRST CENTURY 99 (Michael Szenberg, Lall Ramrattan \& Eric A. Gottesman, eds., 2006). The thought experiment presented in text could be regarded as asking about "hypothetical revealed preferences" or even "unrevealed revealed preferences." 
all offenders. If you remain in doubt, however, consider one more jurisdiction, the United States of America.

The United States is more dependent on plea bargaining than any other nation in the world. It also incarcerates a higher proportion of its population than any other nation. ${ }^{100}$ Could the United States truly have achieved the world record for mass incarceration $^{101}$ while sentencing $95 \%$ of all offenders less severely than they deserved? Until the Lafler-Frye majority acknowledged that post-trial sentences often were inflated to encourage guilty pleas, the official story seemed to be that $95 \%$ of the 2,292,133 Americans behind bars ${ }^{102}$ had been rewarded for their pleas of guilty and therefore sentenced less severely than they deserved (or than was necessary to fully protect the public). Moreover, some observers, including the Lafler-Frye dissenters, still insist that 95\% of America's prisoners received undeserved breaks. These lucky millions gambled and beat the house. ${ }^{103}$

Justice Scalia contends that at least the defendants who entered plea agreements were sentenced less severely than the law says they deserve. ${ }^{104}$ But what law says that the punishments they would have received following conviction at trial are the ones they deserved? One federal law says that all sentences must "comply with" a list of approved purposes of punishment. These purposes include providing just punishment for the offense. They do not include reducing court costs or ensuring conviction in doubtful cases. ${ }^{105}$ Do judges follow this statute when defendants are convicted at trial but not when they plead guilty? Some officials barely maintain the fiction that post-trial sentences are deserved.

100. RoY WALMSLEy, WORLD PRISON POPUlATION LIST 1 (2011), available at http://www.idcr.org.uk/wp-content/uploads/2010/09/WPPL-9-22.pdf ("The United States has the highest prison population rate in the world, 743 per 100,000 of the national population, followed by Rwanda (c. 595), Russia (568), Georgia (547), U.S. Virgin Is. (539), Seychelles (507), St Kitts \& Nevis (495), British Virgin Is. (468), Belize (439), Dominica (431), Bermuda (428), Grenada (423) and Curacao (422).").

101. See generally Michelle Alexander, The New Jim Crow: Mass InCARCERAtion in THE AGE OF COLORBLINDNESS (2010).

102. WALMSLEY, supra note 100 , at 3.

103. See Lafler v. Cooper, 132 S. Ct. 1376, 1398 (2012) (Scalia, J., dissenting). Presumably $95 \%$ of the more than four million Americans under forms of penal supervision other than imprisonment got lucky too. See Lauren E. Glaze \& Erika Parks, Correctional Populations in the United States, 2011, NAT'L CRIM. J., Nov. 2012 at 1, 4 tbl. 3 available at, http://bjs.ojp.usdoj.gov/content/pub/pdf/cpus11.pdf (U.S. Dept. of Justice, Bureau of Justice Statistics 2012).

104. Lafler, 132 S. Ct. at 1398 (Scalia, J., dissenting).

105. See 18 U.S.C. § 3553(a) (2006). 
When Congress creates new crimes and increases sentences, it speaks, not of doing justice, but of giving "tools" to prosecutors. ${ }^{106}$ Consider mandatory minimum sentences like the ones 18 U.S.C. $\S 924(\mathrm{c})$ provides for drug traffickers carrying firearms:

In a recent case, a twenty-two-year-old defendant was arrested on two occasions for possessing both drugs and a firearm. Although he had no criminal record before these arrests, his conviction of the second offense required the court to impose a mandatory minimum sentence of twenty-five years, which the offender would be required to serve after he completed his first sentence. When Judge Myron H. Thompson imposed the total sentence of forty years required by section $924 \ldots$. . he called this sentence "draconian." He noted that not only would the offender's child grow up without a father but his grandchildren, if he had any, would be teenagers or young adults before he was released.

Judge Thompson and other judges are required to impose the mandatory minimum sentences specified by section 924 , but prosecutors have a choice. The [United States] Sentencing Commission reports that, after the exercise of prosecutorial discretion in charging and plea bargaining, only $20 \%$ of the offenders who used firearms to commit drug crimes received the mandatory sentences that section 924 prescribes, and offenders who carried firearms without using them received the section 924 enhancements even less often. ${ }^{107}$

106. The full title of the PROTECT Act is the Prosecutorial Remedies and Tools Against the Exploitation of Children Today Act of 2003. See Pub. L. No. 108-21, 117 Stat. 650 (2003). The full title of the USA Patriot Act is the Uniting and Strengthening America by Providing Appropriate Tools Required to Intercept and Obstruct Terrorism Act of 2001. See Pub. L. 107-56, 115 Stat. 272 (2001). Shortly after the Supreme Court narrowly construed a federal statute proscribing schemes to "deprive another of the intangible right to honest services," see 18 U.S.C. $\$ 1346$ (2006), a Senate committee held hearings titled, "Restoring Key Tools to Combat Fraud and Corruption After the Supreme Court's Skilling Decision." See Restoring Key Tools to Combat Fraud and Corruption After the Supreme Court's Skilling Decision: Hearing Before the S. Comm. on the Judiciary, 111th Cong. (2010). No one in Congress speaks of providing "tools" to defense attorneys.

107. Albert W. Alschuler, Disparity: The Normative and Empirical Failure of the Federal Guidelines, 58 STAN. L. REV. 85, 115-16 (2005) (describing Judge Thompson's opinion in United States v. Washington, 301 F. Supp. 2d 1306 (M.D. Ala. 2004), and some findings reported in United STATES SENTENCING COMMission, FIFTEEN YeARS OF Guidelines Sentencing: An Assessment of How Well the Federal Criminal Justice System is ACHIEVING THE GOALS OF SENTENCING REFORM 90 (2004)). 
If mandatory minimum sentences reflect Congress's determination of the punishments offenders deserve, why don't they bind the officials who determine sentences? Why are they imposed in only one case out of five?

Was Congress unaware that prosecutors effectively determine sentences in $95 \%$ of the cases? Or did Congress willingly play the bad cop, threatening the accused with harsh treatment? Did it knowingly invite prosecutors to play the good cop? Did it supply weaponry that it expected to be brandished in every case but fired only rarely?

At the very least, a regime of plea bargaining enables legislators to indulge in vengeful fantasies and political posturing, secure in the knowledge that no one will pay the fiscal and human costs of implementing these fantasies across the board. When a legislature plans from the outset to allow $95 \%$ of all offenders to avoid the punishments it prescribes, these punishments do not establish a moral norm.

\section{CONCLUSION}

In 1957, in Shelton $v$. United States, ${ }^{108}$ a panel of the Fifth Circuit held plea bargaining unlawful by a vote of two to one. "Justice and liberty are not the subjects of bargaining and barter," Judge Richard Rives declared. ${ }^{109}$ The en banc Fifth Circuit set aside the panel ruling by a vote of three to two, ${ }^{110}$ and the defendant sought review in the Supreme Court.

The Supreme Court did not decide in Shelton whether a guilty plea was involuntary simply because a prosecutor had induced it by promising leniency. The Court would not resolve that question until twelve years later. ${ }^{111}$ Instead, in 1958, the Solicitor General confessed error on a tangential issue, and the Court accepted his confession. ${ }^{112}$

The government's confession of error was peculiar. While referring to all the circumstances of the case, it emphasized that the trial court had failed to conduct an adequate inquiry when it accepted the defendant's guilty plea. The confession of error, how-

108. 242 F.2d 101 (5th Cir.), judgment set aside en banc, 246 F.2d 571 (5th Cir. 1957), rev'd per curiam, 356 U.S. 26 (1958).

109. Id. at 113.

110. Sheldon v. United States, 246 F.2d 571 (5th Cir. 1957), rev'd per curiam, 356 U.S. 26 (1958).

111. See Brady v. United States, 397 U.S. 742 (1970).

112. Shelton v. United States, 356 U.S. 26 (1958). 
ever, failed even to advert to the Fifth Circuit's ruling on this issue. The Fifth Circuit had held unanimously that an inadequate inquiry would not entitle the defendant to withdraw his plea but would require only a hearing on the plea's validity. ${ }^{113}$ Perhaps the Solicitor General did some vote counting, feared that the Supreme Court would forbid plea bargaining, and sought to foreclose such a ruling. ${ }^{114}$

If the Supreme Court had outlawed plea bargaining in 1958, I do not believe that the sky would have fallen. I also believe the American criminal justice system would look very different today. I cannot demonstrate that plea bargaining has been at the root of the many evils that have befallen this system since 1958, but one can make a plausible case that it prompted or facilitated most of them. By lowering the price of imposing criminal punishment, plea bargaining gave America more of it. ${ }^{115}$

Here are a few more thought experiments. If the Supreme Court had outlawed plea bargaining in 1958, would the United States now have as many mandatory minimum sentences, and would they be as harsh? Would it have approved mandatory sentencing guidelines (guidelines the Supreme Court later made advisory)? ${ }^{116}$ Would it have ended parole? ${ }^{117}$ Would it have rushed to punish crack cocaine offenses by treating a single gram of this drug as the equivalent of 100 grams of powder? ${ }^{118}$ Would it have locked up non-violent white-collar first offenders for decades, cal-

113. See Shelton, 242 F.2d at 112 (panel opinion); Shelton, 246 F.2d at 572-73 (en banc opinion).

114. The Solicitor General's confession of error does not appear in most collections of Supreme Court briefs and records. In 1968, however, I located a copy in the Supreme Court library. I told the Shelton story in Alschuler, supra note 10, at 35-37.

115. The prosecutors and judges who produce convictions and sentences in America are usually officials of one set of governments (counties) while prison costs are largely borne by another set of governments (states). Through plea bargaining, courts and prosecutors issue punishment orders cheaply while someone else pays the cost of filling these orders. Far from reducing what taxpayers pay for criminal justice, plea bargaining almost certainly has caused them to pay more.

116. See United States v. Booker, 543 U.S. 220 (2005); cf. United States v. Green, 346 F. Supp. 2d 259, 270 (D. Mass 2004) ("Enhanced plea bargaining is actually the goal of the [federal sentencing] guidelines.").

117. Defendants cannot bargain with a parole board. Leaving much of the determination of sentence to a parole board makes it difficult for prosecutors to promise significant sentence reductions to defendants who will be sentenced to prison following their guilty pleas. See George Fisher, Plea Bargaining's Triumph: A History of Plea Bargaining IN AMERICA 186-94 (2003).

118. See William Spade, Jr., Beyond the 100:1 Ratio: Towards a Rational Cocaine Sentencing Policy, 30 ARIZ. L. REv. 1233, 1250-56 (1996); David A. Slansky, Cocaine, Race, and Equal Protection, 47 STAN. L. REV. 1283, 1290-98 (1995). 
culating their sentences by counting the dollars their crimes $\operatorname{cost}^{119}$ - and possessors of child pornography for a decade or more, calculating their sentences by counting the unlawful images on their computers? ${ }^{120}$ Would it have taken "real offense sentencing" to the same nonsensical extremes? ${ }^{121}$ Would it have six-month trials? Would it conduct lengthy hearings on the appropriate phrasing of Miranda warnings and other irrelevancies? ${ }^{122}$ Would it have approved RICO, the PROTECT Act, the "honest services" statute, and other swaggering tough-on-crime measures?

In a series of articles that began forty-five years ago, I argued that the United States should prohibit plea bargaining ${ }^{123}$ and that doing so was feasible. ${ }^{124}$ Now, however, the criminal justice system has gone off the tracks, and the rails themselves have disappeared. If someone were to propose a Tea Party (or Back to Basics) Movement for Criminal Justice, I might still join, ${ }^{125}$ but I would not give the group more than ten dollars. The time for a crusade to prohibit plea bargaining has passed. ${ }^{126}$

119. See Peter J. Henning, Sentences Get Harsher in White-Collar Cases, N.Y. TIMES DEALB\%K (Apr. 12, 2010), http://dealbook.nytimes.com/2010/04/12/sentences-get-harsherin-white-collar-cases/.

120. See United States Sentencing Commission, 2010 Sourcebook of Federal SENTENCING STATISTICS tbl. 13, available at http://www.ussc.gov/Data_and_Statistics/Annual_Reports_and_Sourcebooks/2010/Table13. pdf (reporting that the average federal sentence for child pornography in fiscal 2010 was 118 months); John Gabriel Woodlee, Note, Congressional Manipulation of the Sentencing Guideline for Child Pornography Possession: An Argument for or Against Deference?, 60 DuKE L.J. 1015, 1025-31 (2011); Rachel Aviv, The Science of Sex Abuse: Is it Right to Imprison People for Heinous Crimes They Have Not Yet Committed?, The New Yorker, Jan. 14, 2013 , available

http://www.newyorker.com/reporting/2013/01/14/130114fa_fact_aviv?currentPage=1.

121. See Alschuler, supra note 107, at 94-95 (noting that federal courts now sentence low-level drug dealers on the basis of the weight of all the drugs possessed by all the member of their drug organizations and even on the basis of drugs these dealers were acquitted of possessing).

122. See Charles D. Weisselberg, Mourning Miranda, 96 CALIF. L. REV. 1519 (2008),

123. See the articles cited in notes $29,40,50,76 \& 78$ supra.

124. See Alschuler, supra note 83.

125. I say that as someone who is appalled by the actual Tea Party's influence on American politics.

126. As late as 1965, a federal court of appeals declared, "It is clear, of course, that a plea of guilty induced by a promise of lenient treatment is an involuntary plea and hence void.” Scott v. United States, 349 F.2d 641, 643 (6th Cir. 1965). The proposition asserted by the court was far from clear in 1965 , but the fact that a court could make this confident pronouncement reveals how different the world is now. As late as 1973, a federal crime commission proposed abolishing plea bargaining "as soon as possible, but not later than

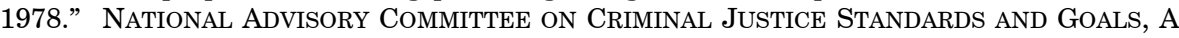
NATIONAL STRATEGY TO REDUCE CRIME 98 (1973). 
Instead, the time may have come for criminal justice scholars to abandon the search for ways to make the criminal justice system fair and principled. Their principal mission today should be to make it less awful. Improving the plea bargaining process should be one of their goals. The decisions in Lafler and Frye take a tiny step in that direction, and the articles published in this symposium point to larger steps-recording plea offers, amending the rules that prohibit judges from participating in plea negotiation, and ensuring that Brady disclosures and other discovery occur at the time the process begins or at least before it ends. ${ }^{127}$

Beyond improving the plea bargaining process, scholars should ask of every proposed reform whether approving it would make trials more or less available. They should seek ways to simplify trial, pretrial, and post-trial procedures. They should resist overcriminalization (especially the expansion of federal criminal law). They should oppose severe punishments. They should support greater funding for indigent defense and seek more effective ways of supplying it. ${ }^{128}$ They should embrace Professor Bibas's proposal for sentencing juries empowered to accept or reject plea agreements. ${ }^{129}$ They should cheer most measures that would reduce the bargaining leverage of prosecutors while booing most measures that would enhance it. Most of all, they should not allow what is familiar to become what is right.

127. See Susan R. Klein, Monitoring the Plea Process, 51 DuQ. L. REV. 559 (2013); Russell D. Covey, Plea Bargaining after Lafler and Frye, 51 DUQ. L. REV. 595 (2013).

128. See Stephen B. Bright \& Sia M. Sanneh, Fifty Years of Defiance and Resistance after Gideon v. Wainwright, 122 YALE L.J. (forthcoming 2013).

129. See BIBAS, supra note 41 , at $156-64$. 
Readers with comments may address them to:

Professor Albert Alschuler a-alschuler@northwestern.edu 


\section{The University of Chicago Law School Public Law and Legal Theory Working Paper Series}

For a listing of papers 1-400 please go to http://www.law.uchicago.edu/publications/papers/publiclaw.

401. Gary Becker, François Ewald, and Bernard Harcourt, "Becker on Ewald on Foucault on Becker" American Neoliberalism and Michel Foucauilt's 1979 Birth of Biopolitics Lectures, September 2012

402. M. Todd Henderson, Voice versus Exit in Health Care Policy, October 2012

403. Aziz Z. Huq, Enforcing (but Not Defending) "Unconstitutional” Laws, October 2012

404. Lee Anne Fennell, Resource Access Costs, October 2012

405. Brian Leiter, Legal Realisms, Old and New, October 2012

406. Tom Ginsburg, Daniel Lnasberg-Rodriguez, and Mila Versteeg, When to Overthrow Your Government: The Right to Resist in the World's Constitutions, November 2012

407. Brian Leiter and Alex Langlinais, The Methodology of Legal Philosophy, November 2012

408. Alison L. LaCroix, The Lawyer's Library in the Early American Republic, November 2012

409. Alison L. LaCroix, Eavesdropping on the Vox Populi, November 2012

410. Alison L. LaCroix, On Being "Bound Thereby," November 2012

411. Alison L. LaCroix, What If Madison had Won? Imagining a Constitution World of Legislative Supremacy, November 2012

412. Jonathan S. Masur and Eric A. Posner, Unemployment and Regulatory Policy, December 2012

413. Alison LaCroix, Historical Gloss: A Primer, January 2013

414. Jennifer Nou, Agency Self-Insulation under Presidential Review, January 2013

415. Aziz Z. Huq, Removal as a Political Question, February 2013

416. Adam B. Cox and Thomas J. Miles, Policing Immigration, February 2013

417. Anup Malani and Jonathan S. Masur, Raising the Stakes in Patent Cases, February 2013

418. Ariel Porat and Lior Strahilevits, Personalizing Default Rules and Disclosure with Big

Data, February 2013

419. Douglas G. Baird and Anthony J. Casey, Bankruptcy Step Zero, February 2013

420. Alison L. LaCroix, The Interbellum Constitution and the Spending Power, March 2013

421. Lior Jacob Strahilevitz, Toward a Positive Theory of Privacy Law, March 2013

422. Eric A. Posner and Adrian Vermeule, Inside or Outside the System? March 2013

423. Nicholas G. Stephanopoulos, The Consequences of Consequentialist Criteria, March 2013

424. Aziz Z. Huq, The Social Production of National Security, March 2013

425. Aziz Z. Huq, Federalism, Liberty, and Risk in NIFB v. Sebelius, April 2013

426. Lee Anne Fennell, Property in Housing, April 2013

427. Lee Anne Fennell, Crowdsourcing Land Use, April 2013

428. William H. J. Hubbard, An Empiritcal Study of the Effect of Shady Grove v. Allstate on Forum Shopping in the New York Courts, May 2013

429. Daniel Abebe and Aziz Z. Huq, Foreign Affairs Federalism: A Revisionist Approach, May 2013

430. Albert W. Alschuler, Lafler and Frye: Two Small Band-Aids for a Festering Wound, June 2013 